\title{
PENGARUH LAYANAN PENGUASAAN KONTEN TERHADAP PENINGKATAN RELIGIUSITAS RESPONDEN KELAS VIII C MTS N 2 BENGKULU UTARA
}

\author{
Lina Zami Hanifah, Hadiwinarto, Syahriman \\ Prodi Bimbingan dan Konseling Fakultas Keguruan dan Ilmu Pendidikan \\ Universitas Bengkulu \\ linazamihanifah@gmail.com, hadiwin@unib.ac.id, syahriman@unib.ac.id
}

\begin{abstract}
ABSTRAK
Penelitian ini bertujuan untuk mendeskripsikan pengaruh layanan penguasaan konten terhadap peningkatan religiusitas responden kelas VIII C MTs N 2 Bengkulu Utara. Penelitian ini merupakan penelitian eksperimen dengan desain penelitian one group pretest dan posttest. Teknik sampling yang digunakan adalah purposive sampling dimana subjek penelitian merupakan responden yang memiliki religiusitas rendahyang berjumlah 10 orang. Teknik pengumpulan data menggunakan instrumen tes. Hasil dari penelitian ini menunjukkan adanya pengaruh yang signifikan layanan penguasaan konten terhadap peningkatan religiusitas pada responden. Hal ini dapat terlihat dari hasil pengujian hipotesis dengan nilai uji $\mathrm{z}$ diperoleh hasil 0,012 (Sig. $<0,05$ ) maka $\mathrm{H}_{0}$ ditolak. Dapat disimpulkan, terdapat pengaruh yang signifikan layanan penguasaan konten terhadap peningkatan religiusitas responden.
\end{abstract}

Kata kunci : layanan penguasaan konten,responden, dan religiusitas

\section{THE INFLUENCE OF THE CONTENT CONTROL SERVICE ENHANCEMENT OF RELIGIUSITY STUDENT CLASS VIII C MTs N 2 BENGKULU NORTH}

\begin{abstract}
This study attempts todescribed the influence total services content to a significant increase in religiousness student of class VIII C MTs N 2 North Bengkulu. The research is research of the experiments with a design to the research done by one group pretest and posttest. Data collection techniques used a purposive samplingis provided by way of 10 of people students a class of VIII Cthat have higher rates of religiousness undeserved favor to the low. Technique data collection use an instrument test. The results of research show that there is the influence of significant services mastery content on increased religiousness to their students.This can be seen from the results of the testing of hypotheses with $\mathrm{z}$ test the results $0,012 \quad$ (Sig. $<0.05$ ) Ho been denied can be conclude. There are significant influence services mastery content on increased students.
\end{abstract}

Keywords : content mastery service, student, and religiusity 


\section{Pendahuluan}

Pendidikan karakter dapat dilakukan dengan cara menanamkan pemahaman nilai religiusitas, yang bertujuan memperbaiki diri dari setiap segi tindakan serta pola perilaku individu yang mengarah pada tatkrama dan nilai kesopanan. Menurut Suyata (dalam Hamid 2013: 2) sinyalemen ini diperkuat oleh sejarah bangsa - bangsa yang selalu mengedapankan karakter sebagai persoalan yang menerpanya. Sebagai contoh revitalisasi bangsa Jerman oleh kekalahan perang dengan Perancis dilakukan dengan pendidikan karakter dan spiritualitas.

Menurut Mangunwijaya (1986: 4) religiusitas adalah seberapa jauh pengetahuan, keyakinan, pelaksanaan dan penghayatan atas agama islam. Sedangkan menurut Ghufron \& Risnawita (2014: 167) religiusitas merupakan tingkat ketertarikan individu terhadap agamanya, dengan memahami sehingga dapat menghayati dan menginternalisasikan ajaran agamanya sehingga berpengaruh dalam segala tindakan dan pandangan hidupnya. Islam merupakan agama yang tidak hanya mengajarkan umatnya untuk beribadah kepada Allah saja namun ikut mengajarkan untuk berbuat kebaikan kepada manusia.

Allah sudah berfirman didalam surat Al-Mujadillah ayat 11 (Anas, 2010: 102) yang artinya “...niscaya Allah akan mengangkat (derajat) orang - orang yang beriman diantaramu dan orang -orang yang diberi ilmu beberapa derajat. Dan Allah Maha teliti apa yang kamu kerjakan". Serta didalam surat Al-Asr ayat 1-3 (Anas, 2010: 100) yang artinya "Demi masa. Sungguh manusia berada dalam kerugian, kecuali orang - orang yang beriman dan mengerjakan kebajikan serta saling menasehati untuk kesabaran. Kedua ayat diatas menerangkan agar umat islam memahami ajaran agamnya dan mengamalkan ilmunya tersebut.

MTs adalah lembaga pendidikan yang setara dengan SMP, namun lebih mengedepankan ajaran agama islam. Sebagai sekolah yang berbasis agama, MTs memiliki kurikulum yang berbeda dengan sekolah umum lainnya, dengan ciri khas mata pelajaran bernuansa agama islam yang lebih banyak. Tujuan kurikulum ini adalah mendidik responden agar memiliki gaya hidup yang sesuai dengan ajaran islam dan memiliki tingkat religiusitas yang lebih tinggi dibanding sekolah umum lainnya.

Akan tetapi fakta lapangan yang terjadi di MTs N 2 Bengkulu Utara yang didapatkan melalui hasil observasi dan wawancara diketahui bahwa respondendi MTs N 2 masih ada yang belum menerapkan religiusitas dengan baik yang ditandai oleh meninggalkan sholat lima waktu, membuang sampah tidak pada tempatnya, tidak menggunakan atribut sekolah, tidak 
mengerjakan PR, berkelahi serta mengobrol saat jam pelajaran. Dalam hal ini sekolah terutama guru mempunyai peranan yang sangat penting dalam mengembangkan pemahaman religiusitas responden. Media yang dapat diberikan salah satunya melalui layanan penguasaan konten. Dimana layanan penguasaan konten ini dapat membantu responden dalam memahami religiusitas.

Layanan ini dilakukan dengan melalui dinamika perorangan, kelompok maupun klasikal. Menurut Prayitno (2004: 2) layanan penguasaan konten merupakan layanan bantuan kepada individu (sendiri-sendiri ataupun dalam kelompok) untuk menguasai kemampuan atau kompetensi tertentu melalui kegiatan belajar. Jadi dalam layanan penguasaan konten harus terdapat suatu konten/kemampuan tertentu yang diajarkan kepada responden dan diharapkan responden mampu menguasai konten tersebut. Sementara menurut Tohirin (2007: 159) mengemukakan bahwa tujuan layanan penguasaan konten, yaitu agar responden menguasai aspek-aspek konten (kemampuan atau kompetensi) tertentu secara terintergrasi, sehingga berguna untuk menambah wawasan dan pemahaman, mengarahkan penilaian dan sikap, menguasai cara-cara tertentu, dalam rangka memenuhi kebutuhan dan mengatasi masalah-masalahnya.

Layanan penguasaan konten adalah kegiatan yang dapat dilakukan secara individual, kelompok dan klasikal yang memberikan responden. Dengan demikian maka melalui layanan penguasaan kontenresponden mendapatkan pemahaman dan mengarahkan sikapnya.Tujuan dalam penelitian ini untuk mendeskripsikan bagaimana religiusitas responden sebelum dan sesudah diberikan treatmen, selanjutnya untuk mendeskripsikan bagaimana pengaruh layanan penguasaan konten terhadap peningkatkan religiusitas responden.

\section{Metode Penelitian}

Dalam penelitian ini, metode yang digunakan adalah metode eksperimen. Penelitian ini dilaksankan di kelas VII C MTs N 2 Bengkulu Utara, pada tanggal 01 maret - 09 april 2018. Sample dalam penelitian ini adalah 10 orang responden kelas VIII C. Desain penelitian yang digunakan dalam penelitian ini adalah one group pretest dan posttest dengan kerangka berpikir sebagai berikut :

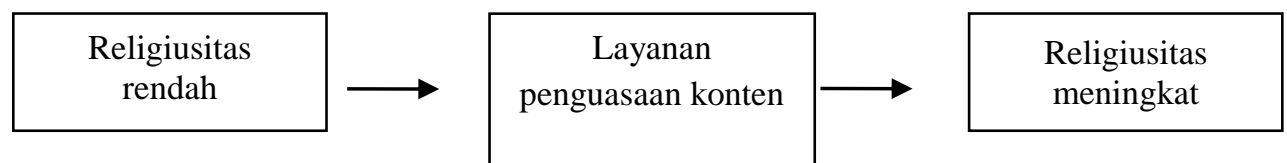

Gambar1 Kerangka berpikir 
Pretest dilakukan untuk mengumpulkan data tentang religiusitas responden di sekolah sebelum diberikan treatmen. Pelaksanaannya dilakukan dengan menggunakan instrumen tes, sedangkan observasi dan wawancara adalah penunjang. Setelah itu dipilih 10 orang responden yang memiliki nilai tes terendah selanjutnya diberikan treatmen berupa pemberilan layanan penguasaan konten sebanyak empat kali pertemuan. Selanjutnya posttest dilakukan untuk mengumpulkan data tentang religiusitas responden di sekolah setelah diberikan treatmen. Adapun cara pengumpulan data sama dengan apa yang dilakukan sebelumnya pada pretest.

Proses eksperimen dalam penelitian ini terdiri dari satu perlakuan yaitu layanan penguasaan konten. Pada tahap awal, responden diajak untuk mempersiapkan diri. Selanjutnya responden diajak untuk melaksanakan layaanan penguasaan konten. Pada tahap inti responden akan diberikan materi selanjutnya responden diajak untuk mengemukakan pendapatnya terkait materi yang dibahas untuk mengetahui pemahaman responden terkait religiusitas. Pada tahap akhir, responden diajak untuk menyimpulkan materi.

Penelitian ini menggunakan instrumen tes untuk pengukuran religiusitas dan untuk mengumpulkan data tetang religiusitas responden. Instrumen dibuat dalam bentuk tes religiusitas. Instrumen ini dibuat berdasarkan tujuh unsur-unsur dari religiusitas, yaitu akidah, peribadatan, dosa, akhlak dan fugsi religiusitas.

Pengujian validitas menggunakan korelasi person dengan cara membandingkan $r$ hitung (pearson correlation) dengan $r$ tabel. Subjek uji cba terdiri dari 29 orang respondenkelas VIII C MTs N 2 Bengkulu Utara. Jika nilai positif dan $\mathrm{r}$ hitung $\geq \mathrm{r}$ tabel, maka item dapat dinyatakan valid dan sebaliknya jika $r$ hitung < $r$ tabel, maka item dinyatakan tidak valid. $R$ tabel dicari pada signifikansi 0,05 dengan uji 2 sisi dan $\mathrm{N}=30 / \mathrm{df}=13$. Berdasarkan angka korelasi tersebut disimpulkan bahwa 17 item valid untuk mengukur religiusitas responden. Butir yang valid diuji reliabilitasnya dengan menggunakan teknik Cronbach's Alpha. Angka reliabilitasnya baik, yaitu 0,759 .

Perlakuan yang diberikan pada penelitian ini adalah layanan penguasaan konten dengan tujuan untuk meningkatkan religiusitas responden melalui pertemuan sebanyak empat kali dimana pemberian materi setiap pertemuannya berbeda. Pada pertemuan pertama dibahas materi mengenai akidah yang menunjuk pada seberapa tingkat keyakinan muslim terhadap kebenaran ajaran-ajaran agamanya, terutama terhadap kebenaran ajaran-ajaran yang bersifat fundamental dan dogmatik. Di dalam keberislaman, isi dimensi keimanan menyangkut 
keyakinan tentang Allah, para malaikat, nabi/rosul, kitab- kitab Allah, surga dan neraka, serta qadha dan qadar.

Pada pertemuan kedua diberikan tema layanan berupa perbadatan dan dosa yang menunjuk pada seberapa tingkat kepatuhan muslim dalam mengerjakan kegiatan-kegiatan ritual sebagaimana disuruh dan dianjurkan oleh agamanya. Dalam keberislaman, dimensi ini menyangkut pelaksanaan segala ibadah dan hubungan timbal balik yang didapatkan dari perbuatan seseorang. Pertemuan ketiga membahas mengenai akhlak ini menunjuk pada seberapa tingkatan muslim berperilakudimotivasi oleh ajaran-ajaran agamanya, yaitu bagaimana individu berelasi dengan dunianya, terutama dengan manusia lain. Selanjutnya pada pertemuan keempat dibahas mengenai fungsi religiusitas agar perubahan perilaku didapatkan. Selanjutnya untuk menguji hipotesis, data-data yang terkumpul akan dianalisis secara statistik melalui uji $z$.

\section{Hasil dan Pembahasan}

Hasil data penelitian untuk pengukuran diperoleh data mean 9,04, standar deviasi sebesar 4,558, dengan skor minimum 1 dan maksimum 16. Pengukuran menggunakan 5 kategori. Kategori tersebut adalah sangat tinggi, tinggi, rata-rata, rendah, dan sangat rendah. Kategori religiusitas ditentukan berdasarkan skor total subjek pada pengukuran dengan menggunakan instrumen tes religiusitas. Adapun peningkatan skor, yaitu:

Tabel 1

Peningkatan Skor Responden

\begin{tabular}{|c|c|c|c|c|c|}
\hline Responden & Pre-test & Kategori & Post-test & Kategori & Peningkatan \\
\hline A & 2 & $\begin{array}{l}\text { Sangat } \\
\text { Rendah }\end{array}$ & 10 & Rata-Rata & 8 \\
\hline B & 5 & Rendah & 11 & Tinggi & 6 \\
\hline $\mathrm{C}$ & 3 & $\begin{array}{l}\text { Sangat } \\
\text { Rendah }\end{array}$ & 12 & Tinggi & 9 \\
\hline $\mathrm{D}$ & 1 & $\begin{array}{l}\text { Sangat } \\
\text { Rendah }\end{array}$ & 9 & Rata-Rata & 8 \\
\hline $\mathrm{E}$ & 6 & Rendah & 14 & $\begin{array}{l}\text { Sangat } \\
\text { Tinggi }\end{array}$ & 8 \\
\hline $\mathrm{F}$ & 5 & Rendah & 16 & $\begin{array}{l}\text { Sangat } \\
\text { Tinggi }\end{array}$ & 11 \\
\hline
\end{tabular}




\begin{tabular}{cccccc}
\hline G & 6 & Rendah & 15 & $\begin{array}{l}\text { Sangat } \\
\text { Tinggi }\end{array}$ & 7 \\
\hline H & 6 & Rendah & 13 & Tinggi & 7 \\
\hline I & 4 & $\begin{array}{r}\text { Sangat } \\
\text { Rendah }\end{array}$ & 11 & Tinggi & 6 \\
\hline J & 3 & $\begin{array}{r}\text { Sangat } \\
\text { Rendah }\end{array}$ & 9 & Rata-Rata & 6 \\
\hline Rata-rata & $\mathbf{4 , 1}$ & $\begin{array}{l}\text { Sangat } \\
\text { Rendah }\end{array}$ & $\mathbf{1 2}$ & Tinggi & $\mathbf{7 , 6}$ \\
\hline
\end{tabular}

Hasil analisis deskriptif melalui Tabel 1 Peningkatan Skor Responden menunjukkan kenaikan skor pada pretest dan posttest responden. Nilai rata-rata pretest 4,1 dengan kategori sangat rendah terjadi kenaikan nilai skor pada posttest menjadi 13,8 dengan kategori sangat tinggi. Uji normalitas dalam penelitian ini menggunakan formulasi Cronbach'Alpha. Kaidah yang digunakan untuk mengetahui normal tidaknya sebaran adalah jika p>0,05 maka sebaran dikatakan normal. Jika $\mathrm{p}<0,05$ maka sebaran dinyatakan tidak normal. Hasil uji normalitas menunjukkan sebaran data pretest dengan $p$ sebesar $0,854(\mathrm{p}>0,05)$ yang berarti sebaran normal dan posttest dengan p 0,539 ( $\mathrm{p}>0,05)$ yang berarti sebaran normal.

Berdasarkan hasil analisis data diperoleh nilai z untuk metode adalah -18,745, dengan nilai signifikansi $0,000(\mathrm{p}<0,05)$ yang berarti hipotesis diterima. Hal ini menunjukkan bahwa ada pengaruh yang signifikan pada tingkat pencapaian religiusitas responden antara sebelum diberikan layanan penguasaan konten dengan yang telah diberikan layanan penguasaan konten. Perbedaan tingkat pencapaian religiusitas responden dengan melihat nilai rata-rata religiusitas responden sebelum diberikan treatmen sebesar 4,10 dengan standar deviasi 1,792 sedangkan nilai rata-rata religiusitas responden sesudah diberikan treatmen sebesar 13,80 dengan standar deviasi 1,476. Hal ini menunjukkan bahwa responden yang mendapatkan layananan penguasaan konten memiliki tingkat religiuistas yang lebih tinggi dibandingkan responden yang belum diberikan layanan penguasaan konten.

Peningkaatan skor religiusitas responden dari sangat rendah ketinggi responden $\mathrm{C}$ dan $\mathrm{I}$ dikarenakan C dan I bersungguh-sungguh dalam mengikuti setiap pertemuan dalam pemberian layanan penguasaan konten, kesungguhan itu ditandai dengan keaktifan $\mathrm{C}$ dan I dalam setiap petemuan yang terlihat dari antusias $\mathrm{C}$ dan I dalam mendengarkan materi serta mengaujukan pertanyaan dan menanggapi persoalan yang dibahas serta berkomitmen tinggi 
untuk menerapkan religiusitas dalam kehidupan sehari-hari, juga terdapat faktor dari luar yaitu dorongan guru BK agar responden bersungguh-sungguh dalam mengikuti kegiatan.

Sementara peningkatan skor responden dari rendah ke sangat tinggi responden E, F, dan $\mathrm{G}$ dikarenakan pada setiap proses pelaksanaan layanan penguasaan konten menunjukan sikap antusias dan kemauan yang tinggi untuk mempelajari religiusitas. Hal ini terlihat dari sikap E, F, dan G pada saat mengikuti proses pelaksanaan layanan penguasaan konten yang memberikan perhatian serius pada materi yang diberikan serta memberikan tanggapan dan pandangannya yaitu mengajukan pertanyaan terkait religiusitas dan memberikan masukanmasukan. Sehingga E, F, dan G memahami hal-hal yang seharusnya dilakukan agar religiusitas $\mathrm{E}, \mathrm{F}$, dan $\mathrm{G}$ meningkat.

Hasil analisis menggunakan SPSS 21.0 for windows dengan uji z-test menunjukkan hipotesis yang mengatakan bahwa ada pengaruh layanan penguasaan konten untuk religiusitas responden kelas VIII C MTs N 2 Bengkulu Utara dinyatakan diterima. Hal ini dapat dilihat dari hasil uji hipotesis yang mengatakan bahwa ada perbedaan nilai posttest yang signifikan antara responden yang belum diberikan treatmen dan yang sudah diberikan treatmen dengan $\mathrm{p}=0,000(\mathrm{p}<0,005)$. Religiusitas pada dasarnya merupakan pembimbing hidup bagi seseorang untuk membedakan benar dan salah yang diyakini dan diterapkan dalam kehidupan. Menurut Prayitno (2004: 2) Layanan penguasaan konten iniperlu diberikan kepada responden untuk menambah wawasan dan pemahaman, mengarahkan sikap, menguasai cara atau kebiasaan tertentu/untuk memenuhi kebutuhannya dan mengatasi masalahnya.

Oleh sebab itu peningkatkan religiusitas responden dapat dilakukan melalui pemahaman dari materi yang diberikan. Bagi 10 orang responden kelas VIII C MTs N 2 Bengkulu Utara yang menjadi sample dalam penelitian ini, pada umunya tidak mengalami kesulitan dalam mengikuti layanan penguasaan konten. Hal ini terlihat saat pelaksanaan eksperimen dimana sebagian besar responden menunjukkan adanya perubahan sikap. Pertemuan pertama hingga pertemuan keempat membahas materi-materi religiusitas. Dari hasil eksperimen yang dilakukan, menunjukkan adanya perubahan pemahaman yang lebih baik dialami setiap responden, hal tersebut terlihat pada setiap pelaksanaan kegitan pelaksanaan layanan penguasaan konten. Selain itu dapat juga dilihat bahwa setiap responden yang mengikuti penguasaan konten memiliki kenaikan rata-rata skor. 
Menurut Prayitno (2004: 2) Layanan penguasaan konten ini perlu diberikan kepada responden untuk menambah wawasan dan pemahaman, mengarahkan sikap, menguasai cara atau kebiasaan tertentu/untuk memenuhi kebutuhannya dan mengatasi masalahnya. Sementara menurut Tohirin (2007: 159) mengemukakan bahwa tujuan layanan penguasaan konten, yaitu agar responden menguasai aspek-aspek konten (kemampuan atau kompetensi) tertentu secara terintergrasi, sehingga berguna untuk menambah wawasan dan pemahaman, mengarahkan penilaian dan sikap, menguasai cara-cara tertentu, dalam rangka memenuhi kebutuhan dan mengatasi masalah-masalahnya.

Menurut Tohirin (2007: 140), secara khusus tujuan layanan penguasaan konten sesuai dengan fungsi-fungsi bimbingan dan konseling yaitu a) Fungsi pemahaman, yang bertujuan agar responden memahami berbagai konten tertentu yang mencangkup fakta-fakta, konsep, proses, hukum dan aturan, nilai-nilai, persepsi, afeksi, sikap, dan tindakan. b) Fungsi pencegahan, yang bertujuan untuk membantu individu agar tercegah dari masalah-masalah tertentu, apabila kontennya terarah kepada terhindarnya individu dari mengalami masalah tertentu. c) Fungsi pengentasan, yang bertujuan untuk mengentaskan atau mengatasi masalah yang sedang dihadapi oleh responden d) Fungsi pengembangan dan pemeliharaan, yang bertujuan untuk mengembangkan potensi yang telah berkembang pada diri responden.

Setiap responden menunjukkan perubahan prilaku yang lebih baik lagi pada setiap pertemuannya. Dimana pada awalnya terdapat beberapa responden belum aktif sudah mulai aktif dan mengemukakan pendapatnya. Dan sudah dapat menanggapi pertanyaan-pertanyaan yang diberikan. Untuk lebih memahami religiusitas diberikan layanan penguasaan konten kepada respondenagar dapat diteriapkan pada kehidupan sehari-hari sehingga mereka dapat berperilaku dan bertindak dengan baik. Dari 10 orang responden tersebut terdapat 3 orang responden yang dikategorikan tinggi, 7 orang responden yang dikategorikan sangat tinggi. Dengan adanya peningkatan pada kategori skor tersebut menunjukkan bahwa terdapat pengaruh layanan penguasaan konten untuk meningkatkan religiusitas responden kelas VIII C MTs N 2 Bengkulu Utara.

\section{Kesimpulan}

Hasil pretest responden sebelum menerima perlakuan memiliki kateori skor rata-rata, yaitu 4,1 . Sedangkan setelah diberikan perlakuan atau treatmen kategori skor menjadi sangat tinggi, yaitu 13,8. Berdasarkan hasil analisis data dapat disimpulkan bahwa layanan penguasaan konten berpengaruh terhadap peningkatan religiusitas responden kelas VIII C 
MTs N 2 Bengkulu Utara, dikarenakan nilai signifikansi $<0,05(0,000<0,05)$. Saran bagi siswa, dengan diberikannya layanan penguasaan konten diharapkan untuk terus meningkatkan religiusitas, dengan mengaplikasikan semua materi yang telah dibahas dalam layanan penguasaan konten, sehingga dapat menjadi pribadi yang lebih baik menurut agama.

Bagi sekolah dapat mendukung dengan baik untuk meningkatkan pemberian layanan penguasaan konten dengan memberikan jam pelajaran yang cukup pada mata pelajaran bimbingan dan konseling. Bagi guru pembimbing, dapat melaksanakan layanan penguasaan konten lebih rutin dan sesuai dengan permasalahan yang dialami siswa, bila diperlukan agar dapat melakukan kolaborasi dengan guru mata pelajaran. Bagi peneliti lanjutan, disarankan dapat menggunakan penelitian ini sebagai bahan acuan untuk mengembangkan penelitian selanjutnya yang terkait dengan pengaruh layanan penguasaan konten terhadap peningkatan religiusitas selain itu, diharapkan dapat melakukan penelitian yang sama dengan metode yang berbeda agar penelitian menjadi lebih luas.

\section{Daftar Pustaka}

Anas, S. (2010). Bimbingan dan Konseling. Bandung: Pustaka Setia.

Ancok \& Suroso. (1995). Psikologi Islami: Solusi Islam atas Problem-Problem Psikologi. Yogyakarta: Pustaka Pelajar.

Ghufron, M. N. \& Rini R. (2014). Teori-Teori Psikologi. Jogjakarta: AR-RUZZ Media.

Khairunnisa, A. (2013). Hubungan Religiusitas dan Kontrol Diri dengan Perilaku Seksual Pranikah Remaja Di MAN 1 Samarinda. Jurnal Psikologi : FISIB Universitas Mulawarman, 220-229.

Hamid A. (2013). Penanaman Nilai - Nilai Karakter Responden SMK Salafiyah Prodi TKJ Kajen Margoyoso Pati Jawa Tengah. Jurnal Pendidikan Vokasi, 2(2), 278-287.

Hadiwinarto. (2010). Penajaman Penilaian Karakter dan Budi Pekerti. Solo: Bahana Media Wirayuda

Mangunwijaya, Y. B. (1986). Menumbuhkan Sikap Religiusitas Anak-anak. Jakarta: Gramedia.

Prayitno. (2004). Kegiatan Pendukung Konseling. Padang: FKIP UNP.

Purnama, T. (2011). Hubungan Aspek Religiusitas dan Aspek Dukungan Sosial terhadap Konsep Diri Selebriti di Kelompok Pengajian Orbit Jakarta. Tesis. Universitas Indonesia.

Tohirin. (2007). Bimbingan dan Konseling di Sekolah dan Madrasah. Jakarta: Rajawali. 